\title{
National Professor A.K.M. Nurul Islam and his achievements
}

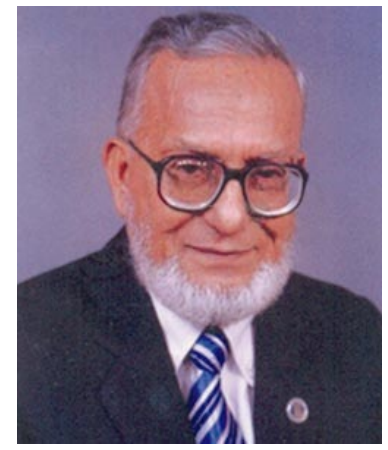

The present Volume 14 of the 'Bangladesh Journal of Plant Taxonomy' has been dedicated as a Commemorative Volume to the respected memory of National Professor A.K.M. Nurul Islam (1928-2006). Prof. Nurul Islam is regarded as the 'Father of Phycology and Limnology' in Bangladesh for his remarkable leadership and outstanding contributions in these fields of Biological Sciences. He had been associated with the Department of Botany of the University of Dhaka for 54 years as a faculty member till his death. The receipt of National Professorship from the Government of Bangladesh in early 2006 demonstrated the ultimate recognition of his contributions at the national level. He was one of the founder members of 'Bangladesh Association of Plant Taxonomists' and was holding the positions of the President of the Association and Chief Editor of its journal the 'Bangladesh Journal of Plant Taxonomy' till his demise.

In the last issue of the Journal (Volume 13, No. 2, December 2006) we announced the sad departure of Prof. Islam on 1 July 2006. There we briefly touched upon his distinguished career as a teacher, scientist and mentor, and also his dedication and contributions to Botanical research and Science as a whole.

Here we are trying to highlight Prof. Islam's achievements ${ }^{1}$ registering all his scientific papers; publications he was associated with as an author, editor and contributor; positions he held in different academic institutions and organizations; journals he edited; and awards and honours he received as appreciations of his contributions to Science.

\section{A. Research publications (chronologically)}

1. Islam, Nurul 1960. Some subaerial green algae from East Pakistan. Trans. Amer. Micros. Soc. 79(4): 471-479. (USA)

2. Islam, A.K.M. Nurul 1961. The genus Cloniophora Tiffany. Revue Algologique n.s.t. 6(1): 7-32. (France)

3. Aziz, K.M.S. and Islam, Nurul 1962. A new species of Fritschiella iyengar from East Pakistan. Trans. Amer. Micros. Soc. 81(2): 185-189. (USA)

4. Islam, A.K.M. Nurul 1962. A new species of Oedocladium from East Pakistan with notes on the genus. Trans. Amer. Micros. Soc. 81(4): 372-379. (USA)

\footnotetext{
${ }^{1}$ This compilation is chiefly based upon Prof. Islam's bio-data regularly updated by Md. Shah Alam of the Department of Botany, University of Dhaka as advised by Prof. Islam.
} 
5. Islam, A.K.M. Nurul 1963. A revision of the genus Stigeoclonium. Beiheft zur Nova Hedwigia 10: 1-165+ pls. 47. J. Cramer Publisher, Weinheim. (W. Germany)

6. Islam, A.K.M. Nurul and Sarma, P. 1963. Two new species of terrestrial Oedogonium from East Pakistan. Trans. Amer. Micros. Soc. 82(1): 74-77. (USA)

7. Islam, A.K.M. Nurul 1964. The genus Cladophorella newly found in East Pakistan. Revue Algologique 7(4): 275-289. (France)

8. Islam, A.K.M. Nurul and Ahia, A.N.M. 1964. Contribution to the knowledge of Chaetophoraceae of Dacca district. Pak. J. Biol. \& Ag. Sc. 7(1): 103-110. (Pakistan)

9. Islam, A.K.M. Nurul and Sarma, P. 1964. Contribution to the knowledge of Oedogoniales of Dacca district, East Pakistan. Pak. J. Biol. \& Ag. Sc. 7(1): 132-135. (Pakistan)

10. Islam, A.K.M. Nurul and Sarma, P. 1964. Preliminary survey of the epizoic Oedogonium growing on the shells of freshwater molluscs in East Pakistan. Rev. Algologique 7(2): 178-186. (France)

11. Islam, A.K.M. Nurul and P. Sarma. 1965. New and rare species and varieties of the Oedogoniales from Dacca district, East Pakistan. Pak. J. Biol. \& Agric. Sci. 8(1): 169188. (Pakistan)

12. Islam, A.K.M. Nurul 1965a. Taxonomic study of the species of Dichotomosiphon and Vaucheria found in East Pakistan. Proc. Pak. Acad. Sci. 2(1): 47-56+ pls. 1-9. (Pakistan)

13. Islam, A.K.M. Nurul 1965b. Occurrence of the genus Sirocladium in East Pakistan. Pak. J. Biol. \& Agric. Sci. 8(2): 264-270. (Pakistan)

14. Islam, A.K.M. Nurul and Khatun, M. 1966. Preliminary studies on the phytoplanktons of polluted waters. Sci. Res. 3(2): 94-109. (Pakistan)

15. Islam, A.K.M. Nurul and Nahar, L. 1967. Preliminary studies on the phytoplanktons of polluted waters. Part II. Blue-green algae. Sci. Res. 4(2\&3): 141-149. (Pakistan)

16. Islam, A.K.M. Nurul and Sarma, D. 1968. The Characeae of East Pakistan. I. Lychnothamnus and Chara. Jour. Asiatic Soc. Pak. 13(3): 357-379 + pls. 1-11. (Pakistan)

17. Islam, A.K.M. Nurul 1969a. Some rare planktonic green algae found in East Pakistan. Pakistan J. Botany 1: 19-32. (Pakistan)

18. Islam, A.K.M. Nurul 1969b. Kirchneriellosaccus lunatus Islam Gen. et Sp. nov., a new member of Chlorococcales. Rev. Alg. n.s.t. 9(4): 348-358 + pls. 18-19. (France)

19. Islam, A.K.M. Nurul 1969. A preliminary report on the phytoplanktons and other algal flora of Chittagong Hill-tracts. Jour. Asiatic Soc. Pak. 14(3): 343-363 + pls. 1-13. (Pakistan)

20. Islam, A.K.M. Nurul and Uddin, M.A. 1969. Studies on the blue-green algae of Dacca district. Dacca Univ. Stud. Part B 17: 85-102. (Pakistan)

21. Islam, A.K.M. Nurul 1970a. The genus Tetrasporidium in East Pakistan. Rev. Alg. 10(1): 85-89. (France)

22. Islam, A.K.M. Nurul 1970b. Contribution to the knowledge of desmids of East Pakistan. Part I. Nova Hedwigia 20: 903-983. (W. Germany) 
Prof. A.K.M. Nurul Islam

23. Islam, A.K.M. Nurul 1970c. Preliminary ecological report on the marine algal flora of the St. Martin's Island, East Pakistan. Jour. Asiatic Soc. Pak. 15(3): 273-282 + pls. 3. (Pakistan)

24. Islam, A.K.M. Nurul and Begum, Z.T. 1970. Studies on the phytoplanktons of Dacca District. Jour. Asiatic Soc. Pak. 15(3): 227-271 + pls. 8. (Pakistan)

25. Islam, A.K.M. Nurul 1972a. The genus Bulbochaete in Bangladesh. Bangladesh J. Bot. 1(12): 1-12. (Bangladesh)

26. Islam, A.K.M. Nurul 1972b. Subaerial algae of Bangladesh. Bangladesh J. Bot. 1(1-2): 1364. (Bangladesh)

27. Islam, A.K.M. Nurul 1972c. New and rare species of some green algae from Bangladesh. Nova Hedwigia. 23: 655-663 + pls. 14. (W. Germany)

28. Islam, A.K.M. Nurul 1973a. A new species of Boodleopsis (Chlorophyta) from Bangladesh. Bangladesh J. Bot. 2(1): 53-67. (Bangladesh)

29. Islam, A.K.M. Nurul 1973b. Freshwater algae of Bangladesh. I. Chlorophyceae, Xanthophyceae and Chrysophyceae. Dacca Univ. Stud. B 21(1): 69-84. (Bangladesh)

30. Islam, A.K.M. Nurul 1973c. The algal flora of Sundarbans Mangrove Forest, Bangladesh. Bangladesh J. Bot. 2(2): 11-36. (Bangladesh)

31. Islam, A.K.M. Nurul 1973d. Freshwater algae of Bangladesh. III. Cyanophyceae. Dacca Univ. Stud. B 21(2): 133-139. (Bangladesh)

32. Islam, A.K.M. Nurul and Uddin, M.A. 1973. Freshwater algae of Bangladesh. II. Cyanophyceae. Dacca Univ. Stud. B 21(2): 127-132. (Bangladesh)

33. Islam, A.K.M. Nurul 1974a. Freshwater algae of Bangladesh. IV. Aphanochaete, Coleochaete and Chaetosphaeridium. Bangladesh J. Bot. 3(1): 35-43. (Bangladesh)

34. Islam, A.K.M. Nurul 1974b. A preliminary list of benthic marine algae from the Bay of Bengal, Bangladesh. Bangladesh J. Bot. 3(1): 83-91. (Bangladesh)

35. Islam, A.K.M. Nurul 1974c. Preliminary studies on the food of some fish. Dacca Univ. Stud. B 22(1): 47-51. (Bangladesh)

36. Islam, A.K.M. Nurul 1974d. Freshwater algae of Bangladesh. VII. Flagellates: Volvocales. Bangladesh J. Bot. 3(2): 7-15. (Bangladesh)

37. Islam, A.K.M. Nurul and Zaman, A.M.S. 1974. Freshwater algae of Bangladesh. VIII. Ulotrichales. Dacca Univ. Stud. B 22(2): 83-98. (Bangladesh)

38. Islam, A.K.M. Nurul, Haroon, A.K.Y. and Zaman, K.M. 1974. Limnological studies of the river Buriganga. I. Physical and chemical aspects. Dacca Univ. Stud. B 22(2): 99-111. (Bangladesh)

39. Islam, A.K.M. Nurul 1975a. Addition to the genus Coleochaete from Bangladesh. J. Asiatic Soc. Bangladesh (Sc.) 1(1): 71-72. (Bangladesh)

40. Islam, A.K.M. Nurul 1975b. Contribution to the study of desmids of Bangladesh. Part II. Dacca Univ. Stud. B 23(2): 31-37. (Bangladesh) 
41. Islam, A.K.M. Nurul and Aziz, A. 1975a. A preliminary study on the zooplankton of the north-eastern Bay of Bengal, Bangladesh. Bangladesh J. Zool. 3(2): 125-138. (Bangladesh)

42. Islam, A.K.M. Nurul and Aziz, A. 1975b. Study of marine phytoplankton from the northeastern Bay of Bengal, Bangladesh. Bangladesh J. Bot. 4(1-2): 1-32. (Bangladesh)

43. Islam, A.K.M. Nurul and Haroon, A.K.Y. 1975. Limnological studies of the river Buriganga. II. Biological aspect. Dacca Univ. Stud. B 23(1): 25-44. (Bangladesh)

44. Islam, A.K.M. Nurul and Saha, J.K. 1975. Limnological studies of the Ramna lake at Dacca. Dacca Univ. Stud. B 23(2): 39-46. (Bangladesh)

45. Islam, A.K.M. Nurul and Zaman, K.M. 1975. Limnological studies of the river Buriganga. III. Biological aspect. J. Asiatic Soc. Bangladesh (Sc.) 1(1): 45-65. (Bangladesh)

46. Islam, A.K.M. Nurul 1976a. Contribution to the study of benthic marine algae of Bangladesh. Bibliotheca Phycologia 19: 1-253 + pls. 7. (W. Germany)

47. Islam, A.K.M. Nurul 1976b. Addition to the species of Vaucheria in Bangladesh. Dacca Univ. Stud. B 24(1): 59-62. (Bangladesh)

48. Islam, A.K.M. Nurul 1976c. Freshwater algae of Bangladesh. VI. Genus Oedogonium. Nova Hedwigia. 27(3-4): 919-925 + pls. 1-5. (W. Germany)

49. Islam, A.K.M. Nurul and Mendes, F. 1976a. Limnological studies of a jheel in Sher-eBangla Nagar. Dacca Univ. Stud. B 24(2): 63-67. (Bangladesh)

50. Islam, A.K.M. Nurul and Mendes, F. 1976b. Proteins from Lyngbya majuscula Harvey ex Gomont and Azolla pinnata R. Br. Bangladesh J. Bot. 5(1-2): 89-92. (Bangladesh)

51. Islam, A.K.M. Nurul and Sarma, D. 1976. The Characeae of Bangladesh. II. The genus Nitella. J. Asiatic Soc. Bangladesh (Sc.) 2(1): 43-61. (Bangladesh)

52. Islam, A.K.M. Nurul and Sarma, P. 1976. Freshwater algae of Bangladesh. V. Genus Oedogonium. Nova Hedwigia. 27: 425-454. (W. Germany)

53. Islam, A.K.M. Nurul and Sobhan, A. 1976. Ecology and periodicity of the members of Zygnemaceae in Dacca district. J. Asiatic Soc. Bangladesh B 1(2): 113-116. (Bangladesh)

54. Islam, A.K.M. Nurul, Chowdhury, B.C. and Begum, S. 1976. The genus Botrydium in Bangladesh. Dacca Univ. Stud. B 24(1): 63-67. (Bangladesh)

55. Karim, M.A. and Islam, A.K.M. Nurul 1976. Eutrophication of the surface water of some lakes studied at Dhaka (Bangladesh). Proc. Inter. Symp. on Eutrophication and Rehabilitation of surface waters. Eutrosym 1976. III. 200-208. (W. Germany).

56. Islam, A.K.M. Nurul 1977. Studies on the members of Zygnemaceae from Bangladesh: I. Mougeotia, Zygnema and Sirogonium. Dacca Univ. Stud. B 25(1): 7-22. (Bangladesh)

57. Islam, A.K.M. Nurul and Paul, S.N. 1977. Limnological studies on Wolffia arrhiza (L.) Wimm. J. Asiatic Soc. Bangladesh (Sc.) 3(1): 111-123. (Bangladesh)

58. Islam, A.K.M. Nurul and Aziz, A. 1977. Studies on the phytoplankton of the Karnaphuli river estuary. J. Bangladesh Acad. Sci. 1(2): 141-154. (Bangladesh) 
Prof. A.K.M. Nurul Islam

59. Islam, A.K.M. Nurul and Mendes, F. 1977a. Studies on the proteins in blue-green algae of Bangladesh. I. Preliminary investigations. Dacca Univ. Stud. B 25(1): 23-27. (Bangladesh)

60. Islam, A.K.M. Nurul and Mendes, F. 1977b. Studies on the proteins in blue-green algae of Bangladesh. II. Extractible proteins. Dacca Univ. Stud. B 25(2): 51-54. (Bangladesh)

61. Islam, A.K.M. Nurul and Uddin, M.A. 1977. Blue-green algae from Dacca, Bangladesh. 1. Chroococcaceae and Pleurocapsaceae. J. Asiatic Soc. Bangladesh (Sc.) 2(2): 75-81. (Bangladesh)

62. Islam, A.K.M. Nurul 1978. A new species of Vaucheria from Bangladesh. Bangladesh J. Bot. 7(1): 13-16. (Bangladesh)

63. Islam, A.K.M. Nurul and Haroon, A.K.Y. 1978. New reports of some members of Chaetophoraceae from Bangladesh. Nova Hedwigia 29(3-4): 537-556. (W. Germany)

64. Islam, A.K.M. Nurul and Hossain, S.K.T. 1978. Algal flora of the ablution tanks of mosques in Dacca city. J. Asiatic Soc. Bangladesh (Sc.) 4(1): 103-113. (Bangladesh)

65. Islam, A.K.M. Nurul and Khair, A. 1978a. Addition to the list of marine algae of St. Martin's lsland. I. Genus Codium Stackhouse. J. Asiatic Soc. Bangladesh (Sc.) 4(1): 123-126. (Bangladesh)

66. Islam, A.K.M. Nurul and Khair, A. 1978b. Report of some phytoplankton from lake Kaptai, Chittagong Hill-Tracts. Dacca Univ. Stud. B 26(2): 53-61. (Bangladesh)

67. Islam, A.K.M. Nurul and Paul, N. 1978. Hydrobiological study of the haor Hakaluki in Sylhet. J. Asiatic Soc. Bangladesh (Sc.) 4(1): 83-91. (Bangladesh)

68. Islam, A.K.M. Nurul and Uddin, M.A. 1978a. Blue-green algae from Dacca, Bangladesh. II. Oscillatoriaceae. Dacca Univ. Stud. B 26(1): 73-84. (Bangladesh)

69. Islam, A.K.M. Nurul and Uddin, M.A. 1978b. Blue-green algae from Dacca, Bangladesh. III. Nostocaceae, Scytonemataceae and Stigonemataceae. Dacca Univ. Stud. B 26(1): 85-93. (Bangladesh)

70. Aziz, A and Islam, A.K.M. Nurul 1979. Marine dinoflagellates from the Bay of Bengal, Bangladesh. J. Bangladesh Acad. Sci. 3(1-2): 41-49. (Bangladesh)

71. Islam, A.K.M. Nurul 1979a. Addition to the list of Oedogoniaceae from Bangladesh. Dacca Univ. Stud. B 27(1): 47-52. (Bangladesh)

72. Islam, A.K.M. Nurul 1979b. Vaucheria longicaulis Hoppaugh from Iraq with a note on the species. Bull. Torrey Bot. Club. 106(3): 167-173. (USA)

73. Islam, A.K.M. Nurul 1979c. Genus Chloroclonium Borzi in Bangladesh. Bangladesh J. Bot. 8(1-2): 113-115. (Bangladesh)

74. Islam, A.K.M. Nurul and Aziz, A. 1979. Algal flora of Moheshkhali Island, Bangladesh. Dhaka Univ. Stud. B 27(2): 105-122. (Bangladesh)

75. Islam, A.K.M. Nurul and Chowdhury, A.R. 1979. Hydrobiological studies of Dhanmondi lake, Dacca. II. Phytoplankton. J. Asiatic Soc. Bangladesh (Sc.) 5(2): 47-57. (Bangladesh) 
76. Islam, A.K.M. Nurul and Hossain, M. 1979. Preliminary studies on the algal flora of Bagerhat, Khulna. J. Asiatic Soc. Bangladesh (Sc.) 5(1): 37-45. (Bangladesh)

77. Islam, A.K.M. Nurul, Rahman, M. and Choudhury, A.R. 1979. Hydrobiological studies of Dhanmondi lake, Dacca. I. Macrophytes and benthic flora. J. Asiatic Soc. Bangladesh (Sci.) 5(1):59-75. (Bangladesh)

78. Islam, A.K.M. Nurul 1980a. Study on Triplastrum found in Bangladesh with a note on its species. Bangladesh J. Bot. 9(1): 1-12. (Bangladesh)

79. Islam, A.K.M. Nurul 1980b. Revision of the members of Oedogoniaceae- some proposals. In: T.V. Desikachary (ed.) Taxonomy of algae, pp. 533-536. University of Madras, Madras. (India)

80. Islam, A.K.M. Nurul and Alam, R.J.M.S. 1980. Members of Cladophoraceae of Dacca district. Dacca Univ. Stud. B 28(1): 61-70. (Bangladesh)

81. Islam, A.K.M. Nurul and Aziz, A. 1980a. Marine diatoms from the Bay of Bengal, Bangladesh. Bangladesh J. Bot. 9(1): 29-35. (Bangladesh)

82. Islam, A.K.M. Nurul and Aziz, A. 1980b. A marine angiosperm from St. Martin's Island, Bangladesh- Halodule uninervis (Forsskal) Ascherson. Bangladesh J. Bot. 9(2): 177178. (Bangladesh)

83. Islam, A.K.M. Nurul and Haroon, A.K.Y. 1980. Desmids of Bangladesh. Int. Revue ges. Hydrobiol. 65(4): 551-604. (W. Germany)

84. Islam, A.K.M. Nurul, Anatunnesa and Haroon, A.K.Y. 1980. Hydrobiological studies in and around Naogaon, Rajshahi. Dacca Univ. Stud. B 28(2): 31-47. (Bangladesh)

85. Watanabe, M. and Islam, A.K.M. Nurul 1980. Freshwater algae from Lake Akan (4). Jap. J. Phycol. 28: 37-45. (Japan)

86. Al-Saadi, H.A., Antoine, S.E. and Islam, A.K.M. Nurul 1981. Limnological investigation in Al-Hammara marsh area in Southern Iraq. Nova Hedwigia 35: 157-166. (W. Germany)

87. Islam, A.K.M. Nurul 1981. Study of algal flora of Tibet and Bangladesh. In: Proc. Symp. on Qinghai-Xizang (Tibet) Plateau. Geological and Ecological studies on Qinghai-Xizang Plateau 2: 1141-1143. Science Press, Beijing. (China).

88. Islam, A.K.M. Nurul and Begum, Z.T. 1981a. Addition to the list of blue-green algae of Bangladesh. I. Dacca Univ. Stud. B 29(1): 49-57. (Bangladesh)

89. Islam, A.K.M. Nurul and Begum, Z.T. 1981b. Addition to the list of blue-green algae of Bangladesh. II. Bangladesh J. Bot. 10(1): 1-15. (Bangladesh)

90. Islam, A.K.M. Nurul and Muniruzzaman, Kh. 1981. Euglenophyta of Bangladesh. I. Genus Trachelomonas Ehr. Int. Revue ges. Hydrobiol. 66(1): 109-125. (W. Germany)

91. Begum, Z.T and A.K.M. Nurul Islam 1982. Preliminary studies on the effects of blue-green algae in rice yield. Dacca Univ. Stud. B 30(1): 145-147. (Bangladesh)

92. Islam, A.K.M. Nurul 1982. Marsh algae from Southern Iraq. Int. Revue ges. Hydrobiol. 67(2): 245-260. (W. Germany) 
Prof. A.K.M. Nurul Islam

93. Islam, A.K.M. Nurul and Aziz, A. 1982. Addition to the list of marine algae of St. Martin's Island, Bangladesh. II. Brown, red and blue-green algae. Nova Hedwigia 36: 643-657. (W. Germany)

94. Islam, A.K.M. Nurul and Hameed, H.A. 1982. Some epizoic algae from Southern Iraq. Bull. Basrah Nat. Hist. Museum 5: 109-115. (Iraq)

95. Islam, A.K.M. Nurul 1983. Gall-formation in Vaucheria spp. by parasitic rotatorian members. Bangladesh J. Bot. 12(1): 87-89. (Bangladesh)

96. Islam, A.K.M. Nurul and Aziz, A. 1983. Najas gracillima (A Br.) Morong. - a new record for Bangladesh. Bangladesh J. Bot. 12(1): 90-92. (Bangladesh)

97. Islam, A.K.M. Nurul and Haroon, A.K.Y. 1983. Studies on Chaetophoraceae from Southern Iraq. Int. Revue ges. Hydrobiol. 68(3): 443-451. (W. Germany)

98. Bhuiya, Z.H, Islam, A.K.M. Nurul, Hashem, M.A., Begum, Z.N.T. and Rahman, M.M. 1984. Effect of blue green algae as biofertilizer on rice. Bangladesh J. Agril. 9(2): 4751. (Bangladesh)

99. Islam, A.K.M. Nurul 1984. Studies on the members of Zygnemaceae from Bangladesh. II. Spirogyra Link. Bangladesh J. Bot. 13(2): 194-213. (Bangladesh)

100. Islam, A.K.M. Nurul 1984. Studies on the genus Vaucheria (Xanthophyceae) in Iraq. Int. Revue ges. Hydrobiol. 69(6): 877-902. (W. Germany)

101. Islam, A.K.M. Nurul 1985. Occurrence of Johannesbaptistia (Cyanophyceae) in Bangladesh. Bangladesh J. Bot. 14(1): 73-75. (Bangladesh)

102. Islam, A.K.M. Nurul 1985. Some new and rare algae from Iraq. Int. Revue ges. Hydrobiol. 70(5): 755-766. (W. Germany)

103. Islam, A.K.M. Nurul and Hameed, H.A. 1985. Check list of algae with a note on the limnological and oeconographic studies in Iraq (1942-1982). Asiatic Society of Bangladesh, pp. 63. (Bangladesh)

104. Islam, A.K.M. Nurul and Haroon, A.K.Y. 1985. Desmids of Iraq. Int. Revue ges. Hydrobiol. 70(6): 877-889. (W. Germany)

105. Islam, A.K.M. Nurul and Morshed, M.G. 1985. Occurrence of diatom-bloom in the coastal area of Bangladesh. Bangladesh J. Bot. 14(2): 185-187. (Bangladesh)

106. Aziz, A and Islam, A.K.M. Nurul 1986. Lagoon algae of St. Martin’s Island, Bangladesh. Dhaka Univ. Stud. Part E 1(1): 45-52. (Bangladesh)

107. Islam, A.K.M. Nurul 1986. New records of algae from Bangladesh. I. Dactylocoocopsis and Onychonema. Bangladesh J. Bot. 15(1): 109-110. (Bangladesh)

108. Islam, A.K.M. Nurul and Mannan, M.A. 1986. Algal flora of some brackishwater shrimp culture ponds at Satkhira. Dhaka Univ. Stud. E 1(1): 7-18. (Bangladesh)

109. Mannan, M.A, Islam, A.K.M. Nurul and Aziz, A. 1986. Use of blue-green algae as biofertilizer. I. A preliminary study with Scytonema mirabile D 610 in pot culture. Dhaka Univ. Stud. E 1(2): 157-160. (Bangladesh)

110. Begum, Z.N.T., Islam, A.K.M. Nurul and Chowdhury, S.B. 1987. Studies on the chemical composition of three green algae. Bangladesh J. Bot. 16(2): 219-220. (Bangladesh) 
111. Islam, A.K.M. Nurul 1987. Studies on the Characeae of Iraq. I. Genus Nitella. Bangladesh J. Bot. 16(2): 229-231. (Bangladesh)

112. Islam, A.K.M. Nurul and Aziz, A. 1987a. New record of algae from Bangladesh. II. Genus Radiococcus Schmidle (Chlorophyta). Bangladesh J. Bot. 16(1): 89-92. (Bangladesh)

113. Islam, A.K.M. Nurul and Aziz, A. 1987b. Addition to the list of marine algae of St. Martin's Island, Bangladesh. III. Red algae. Nova Hedwigia 45(1-2): 211-221. (W. Germany)

114. Islam, A.K.M. Nurul and Begum, Z.T. 1987. New records of algae from Bangladesh. III. Genus Pseudobohlinia (Chlorococcales). Bangladesh J. Bot. 16(1): 103-106. (Bangladesh)

115. Islam, A.K.M. Nurul, Hadi, R.A.M. and Aziz, A. 1988. Studies on the Characeae of Iraq. II.Chara and Nitellopsis. Bangladesh J. Bot. 17(1): 57-64. (Bangladesh)

116. Khan, M.R. and Islam, A.K.M. Nurul 1988. Two new records of green algae from Bangladesh. Bangladesh J. Bot. 17(2): 167-171. (Bangladesh)

117. Khondker, M., Islam, A.K.M. Nurul and Islam, R. 1988. Studies on the primary productivity of Dhanmondi lake. Dhaka Univ. Stud. Part E 3(1): 15-21. (Bangladesh)

118. Khondker, M., Islam, A.K.M. Nurul, Begum, Z.N.T. and Haque, S. 1990. Limnological studies of four polluted ponds in and around Dhaka city with reference to indicator species. Bangladesh J. Bot. 19(1): 51-63. (Bangladesh)

119. Aziz, A., Alam, J. and Islam, A.K.M. Nurul 1991. Studies on the members of Oedogoniales epiphytic on deepwater rice plants near Sonargaon, Bangladesh. Dhaka Univ. Stud. Part E 6(2): 119-123. (Bangladesh)

120. Islam, A.K.M. Nurul 1991a. Phycology. In: Islam, A.K.M. Nurul (ed.), Two Centuries of Plant Studies in Bangladesh and adjacent regions, pp. 97-153. Asiatic Society of Bangladesh, Dhaka. (Bangladesh)

121. Islam A.K.M. Nurul 1991b. Gymnosperms. In: Islam, A.K.M. Nurul (ed.), Two Centuries of Plant Studies in Bangladesh and adjacent regions, pp. 173-174. Asiatic Society of Bangladesh, Dhaka. (Bangladesh)

122. Islam, A.K.M. Nurul and Hadiuzzaman, S. 1991. Pteridophytes. In: Islam, A.K.M. Nurul (ed.), Two Centuries of Plant Studies in Bangladesh and adjacent regions, pp. 163-171. Asiatic Society of Bangladesh, Dhaka. (Bangladesh)

123. Islam A.K.M. Nurul and Khondker, M. 1991. Preliminary limnological investigations of some polluted waters covered by duckweeds. Bangladesh J. Bot. 20(1): 73-75. (Bangladesh)

124. Islam, A.K.M. Nurul, Begum, A. and Akhter, N. 1991. Some observations on the phytogeography of desmids. J. Asiat. Soc. Bangladesh, Sci. 17(2): 171-178. (Bangladesh)

125. Islam, A.K.M. Nurul, Khondker, M. and Haque, S. 1991. Euglenoid algae of four polluted ponds in and around Dhaka city. Bangladesh J. Bot. 20(1): 7-15. (Bangladesh) 
126. Khan, M.R and Islam, A.K.M. Nurul 1991. Additions to the list of new hosts of Cephaleuros viriscens Kunze (Trentepohliaceae) from Bangladesh. Bangladesh J. Bot. 20(1): 77-79. (Bangladesh)

127. Akter, N. and Islam, A.K.M. Nurul 1992. Addition to the lists of desmid flora of Bangladesh. Dhaka Univ. Stud. Part E 7(1): 95-99. (Bangladesh)

128. Begum, A. and Islam, A.K.M. Nurul 1992. New records of desmids for Bangladesh. Dhaka Univ. Stud. Part E 7(1): 91-93. (Bangladesh)

129. Islam, A.K.M. Nurul 1992. Freshwater red algae of Bangladesh. J. Asiat. Soc. Bangladesh, Sci. 18(1): 29-46. (Bangladesh)

130. Islam, A.K.M. Nurul and Khan, M.R. 1992. A new combination of a Coleochaete taxon (C. reptans (Duringer) Islam and Khan comb. nov.) based on Bangladesh materials. Bangladesh J. Bot. 21(2): 287-290. (Bangladesh)

131. Islam, A.K.M. Nurul, Begum, A and Akter, N. 1992. Study on the desmids (Chlorophyta) from Cox's Bazar, Bangladesh. Bangladesh J. Bot. 21(1): 43-51. (Bangladesh)

132. Islam, A.K.M. Nurul, Khondker, M., Begum, A. and Akter, N. 1992. Hydrobiological studies in two habitats at Dhaka. J. Asiat. Soc. Bangladesh, Sci. 18(1): 47-52. (Bangladesh)

133. Hadi, A.M.R., Islam, A.K.M. Nurul, Haroon, A.K.Y. and Al-Saboonchi, A.A. 1993. Marine benthic algae from coastal waters of Iraq. J. Asiat. Soc. Bangladesh, Sci. 19(2): 123144. (Bangladesh)

134. Islam, A.K.M. Nurul 1993. Limnology and pollution of wetlands. In: Nishat, A., Hussain, Z., Roy, M.K. and Karim, A. (eds.), Freshwater Wetlands in Bangladesh: Issues and approaches for management, pp. 123-145. IUCN, Gland. (Switzerland)

135. Islam, A.K.M. Nurul and Islam, M.S. 1993. Hydrophytes, eutrophication and diseases. In: Tilzer, M.M. and Khondker, M. (eds.), Hypertrophic and Polluted Freshwater Ecosystems: Ecological Bases for Water Resource management, pp. 173-178. Proc. Int. Symp. Limnol., 25-28 November 1991. Department of Botany, University of Dhaka, Dhaka. (Bangladesh)

136. Islam, A.K.M. Nurul and Khondker, M. 1993. Some unicellular flagellate algae of Bangladesh. J. Asiat. Soc. Bangladesh, Sci. 19(2): 75-79. (Bangladesh)

137. Khan, M.R. and Islam, A.K.M. Nurul 1993a. New records of green algae from Bangladesh. I. Aphanochaete and Chaetosphaeridium. J. Asiat. Soc. Bangladesh, Sci. 19(1): 49-54. (Bangladesh)

138. Khan, M.R and Islam, A.K.M. Nurul 1993b. Ecology of the chaetophoralean algae of Bangladesh. J Asiat. Soc. Bangladesh, Sci. 19(2): 145-153. (Bangladesh)

139. Khondker, M., Islam, A.K.M. Nurul and Makhnun, A.D. 1993. Study of the growth of a free-floating macrophyte. J. Asiat. Soc. Bangladesh, Sci. 19(2): 103-108. (Bangladesh)

140. Khondker, M., Islam, A.K.M. Nurul and Nahar, N. 1993a. A preliminary study on the growth rate of Spirodela polyrhiza. Dhaka Univ. J. Biol. Sci. 2(2): 197-200. (Bangladesh). 
141. Khondker, M., Islam, A.K.M. Nurul and Nahar, N. 1993b. Study on the biomass of Spirodela polyrhiza and the related limnological factors of some polluted waters. In: Khan, M.S., Khan, M.A.A., Hadiuzzaman, S and Aziz, A. (eds.), Plants for the Environment, pp. 37-40. Proc. $7^{\text {th }}$ Bot. Conf., 13-14 December 1992. Bangladesh Botanical Society, Dhaka. (Bangladesh)

142. Begum, Z.T., Akhter, R., Islam, A.K.M. Nurul and Aziz, A. 1994. Taxonomy of the stigonematalean algae in culture. In: Phang et al. (eds.), Algal Biotechnology in the Asia-Pacific Region, pp. 257-262. University of Malaya.

143. Islam, A.K.M. Nurul and Khondker, M. 1994. New records of algae from Bangladesh. IV. Heteromastix and Gonyostomum. Bangladesh J. Bot. 23(2): 199-203. (Bangladesh)

144. Khan, M.R. and Islam, A.K.M. Nurul 1994a. New records of chaetophoralean algae for Bangladesh-1. Apatococcus, Entocladia, Gloeoplax, Gomontia, Gongrosira. Bangladesh J. Pl. Tax. 1(1): 35-42. (Bangladesh)

145. Khan, M.R. and Islam, A.K.M. Nurul 1994b. New records of chaetophoralean algae for Bangladesh-2. Chaetonema, Chaetopeltis, Cloniophora, Chlorosarcina, Draparnaldia, Pseudendoclonium, Pseudopleurococcus and Spongioplastidium. Bangladsesh J. Plant Taxon. 1(2): 1-15. (Bangladesh)

146. Khondker, M., Islam, A.K.M. Nurul and Makhnun, A.D. 1994. Lemna perpusilla: screening on habitat limnology. Bangladesh J. Bot. 23(1): 99-106. (Bangladesh)

147. Khan, M.R. and Islam, A.K.M. Nurul 1996a. New records of chaetophoralean algae for Bangladesh. 3. Ireksokonia. Bangladesh J. Bot. 25(2): 219-221. (Bangladesh)

148. Khan, M.R. and Islam, A.K.M. Nurul 1996b. New records of Chaetophoralean algae for Bangladesh. Protoderma, Pseudolvella, Trichophilus, Ulvella. Bangladesh J. Pl. Tax. 3(2): 77-85. (Bangladesh)

149. Islam, A.K.M. Nurul 1997. A new record of a Seagrass (Halophila decipiens Ostenfeld) for Bangladesh. Bangladesh J. Plant Taxon. 4(1): 93-97. (Bangladesh)

150. Islam, A.K.M. Nurul and Khondker, M. 1997. New records of some flagellate algae for Bangladesh - 5. Chlamydomonas, Pascherina, Pyrobotrys, Cryptomonas and Chilomonas. Bangladesh J. Plant Taxon. 4(2): 13-23. (Bangladesh)

151. Kassim, T.I., Al-Saadi, H.A., Al-Lami, A.A., Farhan, R.K., Al-Taai, Y.S. and Islam, A.K.M. Nurul 1997. Studies of the algae epiphytic on different hydrophytes in Qadisia Lake, Iraq. J. Asiat. Soc. Bangladesh, Sci. 23(1): 141-152. (Bangladesh)

152. Islam, A.K.M. Nurul 1998. The seaweed resources of Bangladesh. In: Critchley, A.T. and Ohno, M. (eds.), Seaweed Resources of the World, pp. 106-109. Japan International Cooperation Agency. (Japan)

153. Islam, A.K.M. Nurul and Irfanullah, H.M. 1998a. New records of three green algal genera for Bangladesh : Desmatractum, Glaucocystis and Groenbladia. Bangladesh J. Plant Taxon. 5(1): 91-96. (Bangladesh)

154. Islam, A.K.M. Nurul and Irfanullah, H.M. 1998b. New records of desmids for Bangladesh. I. Fifteen taxa. Bangladesh J. Bot. 27(2): 89-96. (Bangladesh) 
Prof. A.K.M. Nurul Islam

155. Khan, M.R. and Islam, A.K.M. Nurul 1998a. New records of subaerial green algae (Trentepohliaceae) for Bangladesh. Bangladesh J. Plant Taxon. 5(1): 47-62. (Bangladesh)

156. Khan, M.R. and Islam, A.K.M. Nurul 1998b. Six new taxa of Chaetophoraceae (Chlorophyta) from Bangladesh. Bangladesh J. Plant Taxon. 5(2): 13-27. (Bangladesh)

157. Khan, M.R. and Islam, A.K.M. Nurul 1998c. Six new taxa belonging to Trentepohlia (Trentepohliales; Chlorophyta) from Bangladesh. Bangladesh J. Plant Taxon. 5(2): 6982. (Bangladesh)

158. Islam, A.K.M. Nurul and Akter, N. 1999. Desmids of Chittagong, Bangladesh - Part 2: Closterium, Docidium, Netrium, Pleurotaenium and Staurastrum. Bangladesh J. Plant Taxon. 6(1): 19-30. (Bangladesh)

159. Islam, A.K.M. Nurul and Begum, A. 1999. Desmids of Chittagong, Bangladesh - Part 1: Actinotaenium, Cosmarium, Euastrum and Micrasterias. Bangladesh J. Plant Taxon. 6(1): 1-17. (Bangladesh)

160. Islam, A.K.M. Nurul and Irfanullah, H.M. 1999a. New records of desmids for Bangladesh. II. Thirteen taxa. Bangladesh J. Bot. 28(2): 117-123. (Bangladesh)

161. Islam, A.K.M. Nurul and Irfanullah, H.M. 1999b. New records of desmids for Bangladesh. III. 24 taxa. Bangladesh J. Plant Taxon. 6(2): 91-104. (Bangladesh)

162. Khan, M.R. and Islam, A.K.M. Nurul 1999a. New taxa of Coleochaetales (Chlorophyta) from Bangladesh. J. Asiat. Soc. Bangladesh, Sci. 25(1): 51-79. (Bangladesh)

163. Khan, M.R. and Islam, A.K.M. Nurul 1999b. New records of Stigeoclonium taxa (Chlorophyta) for Bangladesh. Bangladesh J. Plant Taxon. 6(2): 55-83. (Bangladesh)

164. Islam, A.K.M. Nurul and Irfanullah, H.M. 2000a. Hydrobiological studies within the tea gardens at Srimangal, Bangladesh. I. Aquatic macrophytes. Bangladesh J. Plant Taxon. 7(1): 29-42. (Bangladesh)

165. Islam, A.K.M. Nurul and Irfanullah, H.M. 2000b. New records of eleven algal taxa for Bangladesh. Bangladesh J. Bot. 29(2): 115-120. (Bangladesh)

166. Islam, A.K.M. Nurul and Irfanullah, H.M. 2000c. Addition to the list of marine algae of St. Martin's Island. IV. Codium Stackhouse. Bangladesh J. Plant Taxon. 7(2): 21-26. (Bangladesh)

167. Khan, M.R. and Islam, A.K.M. Nurul 2000. New records of four Coleochaete species (Chlorophyta) for Bangladesh. Bangladesh J. Plant Taxon. 7(1): 15-27. (Bangladesh)

168. Aziz, A., Islam, A.K.M. Nurul and Parvin, R. 2001. Marine algae of St. Martin's Island, Bangladesh. I. New records of Sargassum spp. Bangladesh J. Bot. 30(2): 135-140.

169. Islam, A.K.M. Nurul and Alfasane, M.A. 2001a. New records of some freshwater planktonic algae for Bangladesh : Species of Treubaria, Goniochloris, Tetraedriella and Tetraplektron. Bangladesh J. Bot. 30(2): 131-134.

170. Islam, A.K.M. Nurul and Alfasane, M.A. 2001b. New records of some green planktonic algae for Bangladesh : Phacotus, Planktosphaeria and Nephrochlamys. Bangladesh J. Plant Taxon. 8(2): 51-56. 
171. Islam, A.K.M. Nurul and Irfanullah, H.M. 2001. Some new records of algae for Bangladesh: Cyanarcus, Chloremys, Myrmecia, Selenodictyum, Tetraplektron and Pseudostaurastrum. Bangladesh J. Plant Taxon. 8(2): 1-7.

172. Khan, M.R. and Islam, A.K.M. Nurul 2001. A new record of a subaerial green alga Desmococcus vulgaris (Chaetophoraceae, Chlorophyta) for Bangladesh. Bangladesh J. Plant Taxon. 8(1): 109-111. (Bangladesh)

173. Aziz, A., Islam, A.K.M. Nurul and Jahan, A. 2002a. Marine algae of St. Martin's Island, Bangladesh : III. Red Algae. J. Asiatic Soc. Bangladesh (Sci.) 28(1): 63-70 (Bangladesh).

174. Aziz, A., Islam, A.K.M. Nurul and Jahan, A. 2002b. Marine algae of St. Martin's Island, Bangladesh. IV. New records of red algae. Bangladesh J. Bot. 31(2): 113-116 (Bangladesh)

175. Islam, A.K.M. Nurul and Alfasane, M.A. 2002a. New records of motile green algae for Bangladesh: Phacotus, Pteromonas and Thoracomonas. Bangladesh J. Plant Taxon. 9(1): 15-18. (Bangladesh)

176. Islam, A.K.M. Nurul and Alfasane, M.A. 2002b. Euglenophyceae from Barisal District, Bangladesh. I. Genus Phacus. Bangladesh J. Plant Taxon. 9(2): 3-18. (Bangladesh).

177. Islam, A.K.M. Nurul, Aziz, A. and Jahan, A. 2002. Marine algae of St. Martin's Island, Bangladesh : II. New records of red algae. Bangladesh J. Bot. 31(1): 23-28. (Bangladesh)

178. Islam, A.K.M. Nurul, Mansoor, N. and Begum, Z.N.T. 2002. Taxonomy of cyanobacteria (BGA) involved in the retting of jute. Bangladesh J. Plant Taxon. 9(2): 37-46. (Bangladesh)

179. Islam, A.K.M. Nurul and Alfasane, M.A. 2003. Euglenophyceae from Barisal District, Bangladesh II: Lepocinclis, Strombomonas and Trachelomonas. Bangladesh J. Plant Taxon. 10(1): 15-26. (Bangladesh)

180. Islam, A.K.M. Nurul and Irfanullah, H.M. 2003. Freshwater algae of St. Martin's Island, Bangladesh -I. Bangladesh J. Plant Taxon. 10(2): 33-45. (Bangladesh)

181. Islam, A.K.M. Nurul and Khundker, J. 2003. Algal flora of brackishwater shrimp-culture ponds at Khulna, Bangladesh - I. Cyanophyceae. Bangladesh J. Plant Taxon. 10(2): 5771. (Bangladesh)

182. Aziz, A., Islam, A.K.M. Nurul and Jahan, A. 2004. Peyssonnelia simulans W.-Van Bosse (Rhodophyta) - A new algal record from St. Martin's Island, Bangladesh. Bangladesh J. Plant Taxon. 11(2): 69-71. (Bangladesh)

183. Islam, A.K.M. Nurul and Akter, N. 2004. Desmids from some selected areas of Bangladesh: 2. Genus Staurastrum Meyen. Bangladesh J. Plant Taxon. 11(2): 15-28. (Bangladesh)

184. Islam, A.K.M. Nurul and Alfasane, M.A. 2004. Euglenophyceae from Barisal District, Bangladesh: III. Genus Trachelomonas Ehr. Bangladesh J. Plant Taxon. 11(2): 33-37. (Bangladesh) 
Prof. A.K.M. Nurul Islam

185. Islam, A.K.M. Nurul and Begum, A. 2004. Desmids from some selected areas of Bangladesh: 1. Genus Micrasterias Agardh. Bangladesh J. Plant Taxon. 11(2): 1-14. (Bangladesh)

186. Islam, A.K.M. Nurul, Aziz, A. and Parvin, R. 2004. Marine algae of St. Martin's Island, Bangladesh - II. Brown algae. Bangladesh J. Plant Taxon. 11(1): 1-7. (Bangladesh)

187. Islam, A.K.M. Nurul. and Khundker, J. 2004. Algal flora of brackishwater shrimp culture ponds at Khulna, Bangladesh - II. Bangladesh J. Plant Taxon. 11(1): 69-76. (Bangladesh)

188. Islam, A.K.M. Nurul and Akter, N. 2005. Desmids of some selected areas of Bangladesh. 3. Docidium, Pleurotaenium, Triplastrum and Triploceras. Bangladesh J. Plant Taxon. 12(1): 11-23. (Bangladesh)

189. Islam, A.K.M. Nurul and Alfasane, M.A. 2005. Notes on two green plankton found in Bangladesh. Bangladesh J. Plant Taxon. 12(2): 97-99. (Bangladesh)

190. Islam, A.K.M. Nurul and Irfanullah, H.M. 2005a. Hydrobiological studies within the tea gardens at Srimangal, Bangladesh. II. Algal flora (excluding Chlorophyceae). Bangladesh J. Plant Taxon. 12(1): 33-52. (Bangladesh)

191. Islam, A.K.M. Nurul and Irfanullah, H.M. 2005b. Hydrobiological studies within the tea gardens at Srimangal, Bangladesh. III. Chlorophyceae (excluding desmids). Bangladesh J. Plant Taxon. 12(2): 19-37. (Bangladesh)

192. Islam, A.K.M. Nurul and Irfanullah, H.M. 2005c. Hydrobiological studies within the tea gardens at Srimangal, Bangladesh. IV. Desmids (17 genera). Bangladesh J. Plant Taxon. 12(2): 49-62. (Bangladesh)

193. Islam, A.K.M. Nurul and Akter, N. 2006. Desmids from some selected areas of Bangladesh: 3. Genus Staurastrum Meyen (2). Bangladesh J. Plant Taxon. 13(1): 41-47. (Bangladesh)

194. Islam, A.K.M. Nurul and Irfanullah, H.M. 2006a. Hydrobiological studies within the tea gardens at Srimangal, Bangladesh. V. Desmids (Euastrum, Micrasterias, Actinotaenium and Cosmarium). Bangladesh J. Plant Taxon. 13(1): 1-20. (Bangladesh)

195. Islam, A.K.M. Nurul and Irfanullah, H.M. 2006b. Hydrobiological studies within the tea gardens at Srimangal, Bangladesh. VI. Desmids (Xanthidium, Arthrodesmus, Staurodesmus and Staurastrum). Bangladesh J. Plant Taxon. 13(2): 111-129. (Bangladesh)

\section{B. List of scientific contributions other than research publications}

1. Contributor of the 'Encyclopedia of Flora and Fauna of Bangladesh', volumes on algae, to be published by the Asiatic Society of Bangladesh, Dhaka.

2. Gachgachali (Flora of Bangladesh) (in Bangla), Bangla Academy, Dhaka, pp. 108 (1985). 


\section{Other publications, presentations and lectures}

1. Onno Kono Shur (Some other tune) (a poetry book in Bangla), Hassan Book House, Dhaka, pp. 80 (1992).

2. Numerous popular articles and notes in magazines and national newspapers on plants, science in general, education, history, and culture.

3. Numerous papers presented at scientific meetings, seminars and workshops on algae, plant taxonomy, freshwater ecology, aquatic pollution, ecology and development, wetland conservation, oceanography, marine biology and plant science and biological science in general in Bangladesh as well as abroad (e.g. China, Germany and India).

4. Delivered many thought-provoking lectures as a Chair, Presidents or Fellow of different organizations and institutions.

\section{Books edited}

1. Two Centuries of Plant Studies in Bangladesh and Adjacent Regions. Asiatic Society of Bangladesh, Dhaka, pp. 299 (1991).

2. Plant Science and Man: Problems and prospects. Bangladesh Botanical Society, Dhaka (1992).

3. Bangla Academy Bijnan Biswakosh (Bangla Academy Science Encyclopaedia) (in Bangla) (Biology Section), Volumes 1-5, Bangla Academy, Dhaka (1998-2005).

\section{E. Research projects supervised}

(Sponsored by the UGC)

1. Investigation of high protein-yielding blue-green algae in Bangladesh

2. Survey of freshwater plants of Bangladesh and their utilization

3. Botanical survey of marine and estuarine waters

\section{F. Positions held in institutions and organizations}

1. 54 years' association with the Department of Botany of the University of Dhaka as a Lecturer (1952-1962), Reader (1962-1972), Professor (1972-1990), Supernumerary Professor (1990-2000), Honorary Professor (2001-January 2006) and National Professor (February 2006-1 July 2006)

2. Head and Chairman, Department of Botany, University of Dhaka (between 1964 \& 1975)

3. Founder Dean, Faculty of Biological Sciences, Dhaka University (1975-1977)

4. Visiting Professor, Dept. of Biology, Basrah University, Iraq (1978, 1980-1982)

5. Director, Centre of Advanced Studies in Biological Sciences (1983-1989)

6. President (1985-1986), Vice-President and Secretary, Bangladesh Botanical Society

7. President (1992-93), Vice-President and Treasurer, Asiatic Society of Bangladesh

8. Team Leader of the Bangladesh Govt. (Sci. \& Tech. Ministry) Project on the "Feasibility Study for the Establishment of National Institute of Oceanography in Bangladesh" (1993) 
9. Team Leader, BTRI Mandate Review Committee (2000-2001), sponsored by BARC

10. President (2002-2006) and Vice-President, Bangladesh Association of Plant Taxonomists

\section{G. Editorial positions held}

1. Chief Editor, Bangladesh Journal of Plant Taxonomy (2002-2006)

2. Chief Editor, Bangladesh Journal of Botany for several years

3. Editor, Dhaka University Studies, Part B

4. Editor, Dhaka University Studies, Part E

5. Editor, Bangladesh Journal of Sci. Res. (BAAS)

6. Editor, Journal of the Asiatic Society of Bangladesh (Sci.)

7. Member, Editorial Committee, Journal of the Academy of Sciences

8. Member, Editorial Committee, Journal of Microbiology

9. Ex-member, Advisory Committee for the preparation of the District Gazetteers of Bangladesh (1963-1980)

10. Ex-member, Bangla Academy Journal (Science)

\section{H. Awards and honours received}

1. Fellow, Bangladesh Academy of Sciences (1980)

2. Fellow, Bangladesh Botanical Society (1994)

3. Fellow, Asiatic Society of Bangladesh ( 2004)

4. Jessup Fellowship, National Academy of Science Philadelphia, USA (1959)

5. SEATO Senior Fellowship, in Marine Biology in Australia, New Zealand and Japan (19701971)

6. Gold Medal (Senior Group), Bangladesh Academy of Sciences for contributions in the field of Biological Sciences (1993)

7. Honoured with citations and crest, Dhaka University Alumni Association, along with other 28 senior distinguished teachers of the University of Dhaka for their achievements during the $75^{\text {th }}$ Anniversary Celebration of the University (1996)

8. Eminent Botanist Gold Medal 2002, Bangladesh Botanical Society, with citation during its International Conference held at Dhaka (2003)

9. Honorary Professorship, Dhaka University Syndicate offered after the end of the Supernumerary Professorship (2001)

10. National Professorship, Government of the People's Republic of Bangladesh (February 2006). 


\section{Other important achievements}

1. Prof. A.K.M. Nurul Islam described the algal genus Kirchneriellosaccus Islam (1969). He and his co-workers described about 300 algal species and sub-specific taxa new to science, many of which have been included in the world monographs.

2. Over the past five decades he guided about 40 students for MSc and a few for PhD degrees in the fields of phycology, limnology, hydrobiology and marine biology.

3. External examiner of $\mathrm{PhD}$ theses of i) Auckland University, New Zealand; ii) University of Chittagong, Bangladesh and iii) University of Kalyani, India.

4. Life Member of different learned societies of Bangladesh. He also served as a Member of different national committees of the country established for the development of education and science.

- Haseeb Md. Irfanullah 